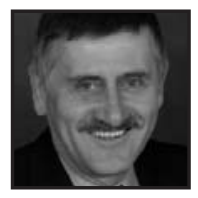

\title{
An EDUCATION Letter
}

\author{
John R. Wiens, University of Manitoba
}

\section{ABSTRACT}

Drawing on some well-known educational thinkers, this letter ${ }^{1}$ to grandchildren argues that education is primarily a human ideal and activity aimed at helping all of us become better, or "educated people." Grandfather further argues that, in our world, all of us are on a lifelong journey to a somewhat illusionary but worthwhile destination, democratic citizenship. He then provides them with some "wayfinders" to aid them on their educational journey, those being virtue, relationships, responsibility and judgment which he claims are the achievements and obligations of educated people. He then promises to help them on their way.

My dear grandchildren, Anais, Nico, Chandler and Raven,

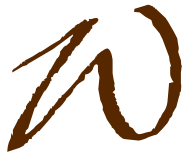

hen you read this letter you will notice that it is meant for all of you and, also, that it is meant for each of you. I am writing this letter because I was asked by some friends to write a commentary about "education." When I think about education I always think about people first, and I think about what a good friend of mine named Hannah Arendt wrote. She said, "education is when you love children enough ..."I can think of no young people whom I love more than you, and I can imagine millions of people the world over who love their children and grandchildren as much as Grandma and I love you. And, like Arendt, I am very excited every time a new child is born, and I was especially happy when each of you was born. Grandma and I want to help with your education-we know that is part of our special relationship to you. This letter contains two things: an invitation to you to talk to us about education and some suggestions to help us think together about education. 
John Dewey, a man who some time ago was also a Dean of Education, said this about education, "Education is not preparation for life, it is life itself." What he meant was that to live well we must continuously educate ourselves or let ourselves be educated, in other words learn from others and the things around us every day. We might also say that we are never completely educated - the job is never over as long as we're alive. There are always other things we can and should learn to become better people, and there are always things we can help other people learn to help them make their lives better. So like another person, Richard Peters, who spent a lot of his time thinking about education, said, "education is like a [lifelong] journey" which starts when we are born and doesn't end until we die-kind of like a never-ending field trip.

For most journeys, we know where we're going and how to get there, and when we're unsure we use maps and a GPS. But even these are of little use unless we have a clear idea of where we hope to end up. If I ask your parents where they want you to end up, they say things like they just want you to be happy and to make other people happy. My good friend, Gary Fenstermacher says happiness is like the North Star-it guides our educational journey but it is more about pointing us in a certain direction than getting there. That's the frustrating thing about this idea we call education-as I shall show later we are never really educated but we can use wayfinders like we do with a GPS to keep us on track. The wayfinders I like are virtue, relationships, responsibility and judgment.

Education has always been about learning how to live a better life. Years ago a man called Aristotle said that in order to live well everyone had to achieve certain virtues, which are habits of the mind and ways of being. He said one had to be humble and courageous, patient and kind, curious and thoughtful. If we are humble we are not boastful or dishonest-we accept that there are lots of things we don't know and that we can learn things from other people. If we are courageous we are open to learning new things and trying to do things differently. If we are patient we know that for something truly important to happen usually takes time. If we are kind we give others the benefit of the doubt even if we disagree, but having thought of what would serve others best, we do offer our thoughts freely without jealousy or anger. If we are curious we try to understand why things are the way they are and how they came to be that way, and if we are thoughtful we try to imagine how they might be better for each person and everybody, including ourselves. For Aristotle, an "educated person" was virtuous, and democracies required educated, in other words, virtuous people. 
What I want for each of you is to be an "educated person." What I want for all of us is to be "educated people." But how do we become virtuous? Jean-Jacques Rousseau, a wild and crazy guy, thought we should live our lives in tune with nature. First, children can be considered "educated" for their age if they "act their age." Children are not adults, and should neither be expected nor forced to think or act like adults. Second, he thought that as we get older we must have a natural right to learn and contribute the way we want to. Third, the natural world is an important part of human lives and, if we hope to live better lives, we must honour and care for it ... and sometimes follow it. An "educated person" has a relationship with his or her own nature, and respects the nature of those around him or her and the nature of all of us put together on this planet, as well as nature itself.

However, we've learned that following nature alone is not good enoughwe must also have relationships with people. Before we learn to read and write we already learn that people expect us to do some things on our own. By watching our parents, teachers and others and listening to their advice (sometimes their scolding), we learn manners, the right way to do things like eating, what clothes to wear when and things like that-in other words, we learn how we do things "so we get along better around here." Because we live among a lot of people, we need to learn to control natural reactions like temper tantrums, selfishness and jealousy. Therefore, sometimes overcoming our nature so that we can have good relationships is what it means to be an educated person.

About the time we become teenagers, we realize that more than ever we don't always want to do what adults tell us or want us to do. We want to make up our own minds and our own rules ... we want to be our own boss. This is a very hard and confusing but important time of life-we make decisions that aren't good for us or others. It is hard not only for us but also for others around us. We test our parents' and teachers' patience. We do awful things to our brothers and sisters, and sometimes to our friends. By being unreasonable we are hopefully learning to be reasonable. By being hard to get along with we're learning how to get along with others on our own terms, something which will become very important later in life. It is the time when we hope that the relationships we formed earlier will see us through. It is also the time when we begin to understand that each of us has personal responsibilities which go beyond just getting along with others. Those responsibilities we might call civic responsibilities like being good democratic citizens contributing to making our communities and our world better. 
When I was a high school teacher the teenagers in my classes were very dependent upon who I was, what I stood for and how I could communicate that I wanted them to be like me in virtuous ways. But my responsibility had another face which, according to another good friend, Jean Bethke Elshtain, was to pass on the best things in the world to the next generation. She said "education is always about what society deems to be meaningful and worthwhile." She also said that if we want to live in a democracy we must take seriously our part in making it reality. Both democracy and education are better when it is considered everybody's business and everybody's responsibility. My good friend, Nel Noddings talks about this as living an ethic of care-actively caring for ourselves, others and the world of nature and people. Democratic citizens as "educated people" take responsibility for the way the world is and try to make it better. Education is about being ready to accept our responsibility in keeping democracy alive and healthy.

Please allow a little aside-today our responsibility to the world is even greater than it was when I started teaching, because technology allows me to imagine myself speaking to absolutely everyone else on earth even though I may never meet them any other way than online. So, to be "educated" now I not only have to live a responsible personal life, but I also have to take into account everyone else's life and how I might help them become more "educated." It's a tough act to get right—it takes all my time and energy ... but I would not have it any other way.

The last "wayfinder" I use in my life GPS is judgment-judging how to live a moral life and contributing to a world where we can all live moral lives. Judgment is doing the right thing at the right time in the right way for the right reasonsvirtuous responsible relationships with others and with our society. We can learn how and what to judge by listening carefully to people like Aristotle, Arendt, Dewey, Peters, Fenstermacher, Elshtain, Noddings and, yes, even Rousseau because as Arendt says, "Education is [also] about loving the world enough." I think to be "educated" is to be a good judge, one who cares about others, oneself and the world, who is open to being judged by caring others and who all the while imagines how his or her life and the world could be better. A good judge tries to make sure that no one is left out and that everyone is treated fairly. Of course, these are ideas which need a lot more discussion. Fortunately, in a democracy we can discuss these things freely, and our education hopes to make us ready to engage wisely in these discussions when the opportunities present themselves or, even more importantly, to give us the courage and confidence to create those moments ourselves. 
You may have noticed that I have not talked a lot about school. That's because, while I think school is an important part of your education, it so often is talked about as if it's your whole education ... which it is not. The fact is that schools only take up a small part of your life, and sometimes schools forget that education is their first responsibility. But that's a topic for another letter.

Anyway, that's a lot of words to get to what I really wanted to say. I promise each one that, as long as Grandma and I have our wits about us and it's OK with you, we will walk by your side and that of your parents as you make your own sense of your own educational journey. This is an invitation to each of you and all of you to talk to us about the things in this letter. We also hope and pray that you will also do the same-walk and talk — with and for each other as cousins. There is nobody who is not meant to be educated, and there is no one who is never in need of more education than he or she has, and there is no one who doesn't deserve the support and help of those who love him or her.

May you enjoy the journey!

Love always

Papa

\section{Note}

1. In order to maintain the authenticity and integrity of the epistolary format used here, the author and date references do not appear in the body of the letter itself. However, the full reference citations are provided below. 


\section{References}

Arendt, H. (1968). Between past and future. New York: Penguin.

Dewey, J. (1916). Democracy and education. New York: Dover.

Elshtain, J.B. (1993). Democracy on trial. Toronto, Canada: Anansi.

Fenstermacher, G. (2000)."What is the difference between the North Star and Northfield? How educational goals and ideals become confused." In Summer Institute for Superintendents on Probing National Issues in Education. University of Michigan, Ann Arbor.
Morgan, M.L. (ed.) (1992). Aristotle, Nicomachean ethics. In Classics of moral and political theory. Cambridge, England: Hackett (pp. 232-382).

Noddings, N. (1992). The challenge to care in schools. New York: Teachers College.

Peters, R.S. (ed). (1967). The concept of education. New York: Routledge and Kegan Paul.

Rousseau, J-J. (1993). Emile. London: Everyman.

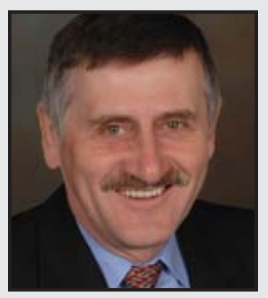

John R. Wiens is completing his $45^{\text {th }}$ year as a teacher. He has been a classroom teacher, principal, superintendent and is now a dean. He is a past president of MTS, CEA, MERC, ACDE and a past chair of the Universities Grants Commission. His academic interests focus on democracy and peace as central human concepts. John recently co-edited a book, Why Do We Educate? Renewing the Conversation, with longtime friend and colleague, David Coulter. Most importantly, he is the father of two teachers and the grandfather of four "pre-teachers," relationships which have inspired his latest involvement as vicechair of the Canadian Centre for Child Protection. 